\title{
ZBIEG UBEZPIECZEŃ EMERYTALNEGO I RENTOWEGO ZLECENIOBIORCY. WYBRANE ZAGADNIENIA
}

\begin{abstract}
Streszczenie. W artykule przedstawione zostały wady i zalety podlegania ubezpieczeniu społecznemu przez zleceniobiorców, na gruncie ustawy z dnia 13 października 1998 o systemie ubezpieczeń społecznych. Publikacja ukazuje zasady zbiegu tytułów w ubezpieczeniach emerytalnym i rentowym. Analizie poddany został także obecny model kumulacji tytułów w ubezpieczeniu społecznym. W końcowej części rozważań autor przedstawia alternatywny model jednolitego obciążenia składką dochodów ubezpieczonych.

Slowa kluczowe: ubezpieczenie społeczne, ubezpieczenie emerytalne, zleceniobiorca, umowa o pracę, umowa zlecenie.
\end{abstract}

\section{UWAGI WSTĘPNE}

Zbieg tytułów w ubezpieczeniach emerytalnym i rentowym stanowi element konstrukcji systemu ubezpieczeń społecznych. Ma on na celu uelastycznianie podlegania ubezpieczeniom emerytalnym i rentowym. Wybór modelu zbiegu tytułów, którego pochodną jest obciążenie lub nie przychodu składką, może prowadzić do preferowania form zatrudnienia objętych niższym obciążeniem przychodu - model autonomicznego obciążenia źródeł dochodu, bądź też wybór podstawy zatrudnienia może być neutralny w sytuacji, gdy wysokość składki nie jest uzależniona od rodzaju stosunku prawnego łączącego jego strony - model jednolitego obciążenia źródeł przychodu (Krajewski 2018, 1-4).

Celem niniejszej publikacji jest ukazanie zasad kumulacji tytułów ubezpieczenia w ramach stosunku pracy, umowy zlecenia oraz innych umów o świadczenie usług, do których zgodnie z przepisami ustawy z 23.04.1964 r. - Kodeks cywilny (Dz.U. z 2019 r., poz. 1145 ze zm.) stosuje się przepisy o zleceniu, a ponadto wskazanie optymalnego modelu zbiegu tytułów w ubezpieczeniach społecznych. Z uwagi na przyjęty podział i zakres zagadnień poruszanych w poszczególnych artykułach, pominięto kwestię kwalifikacji prawnej umów na gruncie prawa pracy i ubezpieczeń społecznych.

* Uniwersytet Łódzki, Wydział Prawa i Administracji, Katedra Prawa Ubezpieczeń Społecznych i Polityki Społecznej, marcin.krajewski@wpia.uni.lodz.pl 


\section{EWOLUCJA ZLECENIA JAKO TYTULU UBEZPIECZENIA W USTAWIE O SYSTEMIE UBEZPIECZEŃ SPOŁECZNYCH}

Ustawa z 13.10.1998 r. o systemie ubezpieczeń społecznych (Dz.U. z 2019 r., poz. 300 ze zm. - SysUbSpołU) zachowała obowiązujący na gruncie poprzednich regulacji model autonomii poszczególnych tytułów ubezpieczenia, ujednolicając jednak zasady podlegania ubezpieczeniom społecznym. Szczególną ochroną na gruncie ustawy objęto osoby pozostające w stosunku pracy. Wśród tytułów niepracowniczych szczególną uwagę ustawodawca poświęca prowadzeniu działalności pozarolniczej oraz świadczeniu usług przez zleceniobiorców. Zasady podlegania ubezpieczeniom emerytalnemu i rentowemu przez zleceniobiorców stanowiły przedmiot licznych nowelizacji, zarówno gdy chodzi o definicję tytułu zleceniobiorcy, jak i konstrukcję zbiegu zlecenia z innymi tytułami ubezpieczenia społecznego.

$\mathrm{Na}$ gruncie ustawy obowiązek ubezpieczenia społecznego oraz podstawa wymiaru składki są uzależnione od posiadanego tytułu ubezpieczenia społecznego. W ubezpieczeniach emerytalnym i rentowych można wyróżnić kilka zasad nadrzędnych, jak: obowiązek podlegania ubezpieczeniom z co najmniej jednego tytułu ubezpieczenia, obowiązek kumulacji składki do osiągnięcia minimalnego wynagrodzenia za pracę, hierarchiczne położenie tytułów ubezpieczenia, szczególna ochrona pracowników, a ponadto elastyczność podlegania ubezpieczeniom emerytalnemu i rentowym przez nie-pracowników. T. Bińczycka-Majewska, analizując treść art. 9 SysUbSpołU, dokonała podziału form aktywności zawodowej pozostających w zbiegu na: tytuły objęte bezwzględnym pierwszeństwem (m.in. stosunek pracy), tytuły objęte zasadą pierwszeństwa w czasie (m.in. zlecenie, działalność pozarolnicza), tytuły względne ubezpieczenia społecznego oraz tytuł ubezpieczenia dobrowolnego (Bińczycka-Majewska 2000, 2; Bińczycka-Majewska 2007, 16). Wprowadzony w analizowanym przepisie hierarchiczny podział poszczególnych tytułów ubezpieczenia oraz przyjęte zasady kumulacji tytułów umożliwiły ograniczenie podstawy wymiaru składki w przypadku wykonywania kilku form aktywności zarobkowej objętych obowiązkowym ubezpieczeniem społecznym. Przyjęta początkowo konstrukcja tytułu ubezpieczenia jako umowy łączącej jej strony, a nie zbioru czynności w ramach stosunku zobowiązaniowego, umożliwiła, w początkowym okresie obowiązywania ustawy, szeroką multiplikację tytułów ubezpieczenia (Kurzych 2015, 333 i n.). W praktyce najczęściej kumulowane były umowa o pracę oraz umowy cywilnoprawne zawierane przez pracownika oraz pracodawcę. Często występującym zjawiskiem było także zawieranie przez zleceniodawcę oraz zleceniobiorcę kilku umów zlecenia. Multiplikacja umów umożliwiała opłacanie składki od części wynagrodzenia osiąganego przez pracownika czy zleceniobiorcę.

Zgodnie z art. 6 ust. 1 pkt 4 SysUbSpołU w brzmieniu z 1998 r., za zleceniobiorcę uznano osobę wykonującą pracę na podstawie umowy agencyjnej lub 
umowy zlecenia lub kilku takich umów, jeżeli zostały zawarte z jednym zleceniodawcą na czas dłuższy niż 14 dni, a okres przerwy między nimi wynosi mniej niż 60 dni. Ustawodawca wprowadził więc konwencjonalną granicę uzależniającą obowiązek ubezpieczenia nie od wysokości osiąganego przychodu, a od długości zawartej przez strony umowy. I. Jędrasik-Jankowska powiązała minimalny okres trwania umowy zlecenia, skutkujący powstaniem tytułu obowiązkowego ubezpieczenia, z kategorią stałego źródła dochodu (Jędrasik-Jankowska 1999, 19). Takie ujęcie zlecenia jako tytułu ubezpieczenia miało tę zaletę, że wyłączało z ubezpieczenia umowy incydentalne, z których przychód byłby niski. Przyjęta regulacja zawierała jednak istotną wadę, a mianowicie umożliwiała zawieranie umów zlecenia na okres krótszy niż 15 dni, co pozwalało uniknąć opłacania składek przez zleceniodawców. Wraz z uchwaleniem ustawy z dnia 17.12.1998 r. o emeryturach i rentach z Funduszu Ubezpieczeń Społecznych (Dz.U. z 2018 r., poz. 1270), zasady podlegania ubezpieczeniom emerytalnemu i rentowym przez zleceniobiorców zmodyfikowano, przez dodanie w art. 6 ustępu 5 SysUbSpołU. Powoływany przepis wprowadził obowiązek ubezpieczenia zleceniobiorcy i osób z nim współpracujących, wykonujących czynności na rzecz jednego zleceniodawcy na podstawie umów agencyjnych lub zlecenia krótszych niż 15 dni, jeżeli przerwy pomiędzy tymi umowami były krótsze niż 60 dni, a po ich zsumowaniu łączny okres świadczenia usług wynosił co najmniej 15 dni. Zmiana ta miała na celu uszczelnienie systemu i uniemożliwienie unikania opłacania składek przez zawieranie kilku umów krótkoterminowych.

Taki stan prawny obowiązywał przez okres jednego roku. Ustawodawca dokonując ewaluacji obowiązujących przepisów, ustawą z dnia 23.12.1999 r. o zmianie ustawy o systemie ubezpieczeń społecznych oraz niektórych innych ustaw (Dz.U. z 1999 r. Nr 110, poz. 1256) uchylił art. 6 ust. 5 SysUbSpołU oraz zmodyfikował art. 6 ust. 1 pkt 4 SysUbSpołU. W wyniku nowelizacji obowiązkiem ubezpieczenia objęto zleceniobiorców niezależnie od długości trwania umowy. Modyfikacja pojęcia zleceniobiorcy wynikała przede wszystkim z podejmowanych przez zleceniodawców prób unikania opłacania składek na ubezpieczenie społeczne. Pojęcie zleceniobiorcy określone w art. 6 ust. 1 pkt 4 SysUbSpołU rozszerzono ponadto o osoby świadczące usługi na innej podstawie niż umowa zlecenie, o ile do tej umowy stosuje się zgodnie $\mathrm{z}$ art. 750 Kodeksu cywilnego przepisy dotyczące zlecenia. Przyjęta regulacja stanowiła odpowiedź na powszechnie występujące zjawisko zawierania umów o świadczenie usług innych niż zlecenie, co skutkowało wyłączeniem takich umów z ubezpieczenia. Należy zatem podkreślić, że omawiana zmiana miała na celu przede wszystkim uszczelnienie systemu ubezpieczeń, a tym samym zwiększenie przychodów Funduszu Ubezpieczeń Społecznych (FUS). Nowelizacja przepisów, zapewniając zleceniobiorcom szerszą ochronę, wyznaczyła kierunek zmian pozycji prawnej zleceniobiorcy na gruncie ustawy o systemie ubezpieczeń społecznych. 
Druga z istotnych zmian, wprowadzona nowelizacją z 1999 r., polegała na wyeliminowaniu możliwości optymalizacji wysokości należnej składki poprzez zawieranie umów cywilnoprawnych $\mathrm{z}$ własnym pracodawcą lub innym podmiotem świadczącym usługi na rzecz pracodawcy, z którym pracownik pozostawał w stosunku pracy. W efekcie wprowadzonych zmian, umowy cywilnoprawne zawierane $\mathrm{z}$ własnym pracodawcą utraciły status samodzielnych tytułów ubezpieczenia. Jak wskazał SA we Wrocławiu wyrokiem z 28.03.2017 r. (III AUa 1114/15, opubl. LEX nr 23948859), „dla celów ubezpieczeń społecznych, umowy takie są traktowane jak świadczenie pracy w ramach stosunku pracy łączącego pracodawcę z pracownikiem". Pierwotnie pracodawca mógł znacząco obniżyć podstawę wymiaru składki na ubezpieczenie społeczne, zawierając ze swoim pracownikiem umowę zlecenia albo umowę agencyjną. Obowiązkiem ubezpieczenia obejmowano wyłącznie umowę o pracę, jako tytuł bezwzględnego ubezpieczenia, natomiast umowa zlecenie, niezależnie od przychodu osiąganego ze stosunku pracy, stanowiła tytuł ubezpieczenia dobrowolnego. Większość z takich umów zlecenia nie była zgłaszana do dobrowolnego ubezpieczenia emerytalnego i rentowych. Umowy cywilnoprawne zawierane z pracownikami były masowo stosowane np. w transporcie czy sektorze budowlanym. J. Skoczyński, krytykując przepis art. 8 ust. 2 a SysUbSpołU, wskazał, że „ustawodawca, wartościując zawierane umowy, nadużył konstrukcji fikcji prawnej, tj. sprzecznego z rzeczywistością założenia, że dana osoba, rzecz lub sytuacja ma określoną cechę, aby osiągnąć słuszny cel, którego inaczej osiągnąć się nie da" (Skoczyński 2000, 24). Z kolei, jak zauważył J. Jończyk, „szerokie rozumienie pojęcia pracownika na gruncie art. 8 ust. 1 SysUbSpołU tworzy fikcję prawną i ma na celu przeciwdziałanie praktyce wejścia do lub wyjścia z systemu" (Jończyk 2003, 106). Moim zdaniem, przyjęty kierunek zmian należy ocenić pozytywnie, gdyż usunięto liczne wątpliwości interpretacyjne, a ponadto utrzymano poziom ochrony przyznany pracownikom, którzy w sytuacji stosunkowo wysokiego bezrobocia nie mieli wpływu na kształt stosunku łączącego ich z podmiotem zatrudniającym. Warto wskazać, że przyjęte rozwiązanie do dziś z powodzeniem chroni ubezpieczonych, a jego kształt przez dwie dekady nie uległ zmianie.

Istotnej modyfikacji zakresu ochrony zleceniobiorców dokonano poprzez dodanie w art. 9 SysUbSpołU ustępu 1a oraz ustępu 1b. Powoływane przepisy wprowadziły obowiązkowe ubezpieczenie zleceniobiorców w sytuacji, gdy przychód określony w umowie, osiągnięty z tytułów objętych bezwzględnym pierwszeństwem (m.in. stosunku pracy), był niższy niż minimalne wynagrodzenie. $\mathrm{W}$ takim przypadku, obowiązkiem ubezpieczenia obejmowane są kolejne tytuły ubezpieczenia (np. umowy zlecenia), aż do osiągnięcia podstawy w wysokości minimalnego wynagrodzenia. Co istotne, kumulacja tytułów oznacza, że podstawę wymiaru składki ze zlecenia stanowi przychód z umowy, a nie jego część niezbędna do uzupełnienia podstawy wymiaru składki do minimalnego wynagrodzenia. Od 1 stycznia 2017 r., zgodnie z art. 8a ustawy z 10.10.2002 r. o minimalnym 
wynagrodzeniu za pracę (Dz.U. z 2017 r., poz. 847 ze zm.), umowę zlecenia objęto minimalną stawką godzinową. Po wejściu w życie tego przepisu zleceniobiorcy świadczący usługi w wymiarze godzin odpowiadającym stosunkowi pracy uzyskali podstawę wymiaru składki odpowiadającą minimalnemu wynagrodzeniu za pracę, a tym samym każda kolejna umowa będzie objęta dobrowolnym ubezpieczeniem emerytalno-rentowym.

Na mocy ustawy z dnia 1.07.2005 r. o zmianie ustawy o emeryturach i rentach z Funduszu Ubezpieczeń Społecznych oraz ustawy o systemie ubezpieczeń społecznych (Dz.U. z 2005 r. Nr 169, poz. 1412) wprowadzono art. 9 ust. 2a SysUbSpołU regulujący zasady zbiegu pozarolniczej działalności gospodarczej oraz zlecenia. Do nowelizacji oba tytuły objęte były zasadą wyrażoną w art. 9 ust. 2 SysUbSpołU, tj. zasadą pierwszeństwa w czasie. Nakazywała ona objęcie ubezpieczeniem tego tytułu, który powstał najwcześniej, umożliwiając jednocześnie zmianę tytułu ubezpieczenia. Na gruncie przepisów obowiązujących przed nowelizacją powszechna była praktyka składania przez przedsiębiorców wniosków o zmianę tytułu ubezpieczenia i objęcie ubezpieczeniem z tytułu zlecenia. $\mathrm{Z}$ uwagi na brak minimalnej podstawy wymiaru składki ze zlecenia, można było w ten sposób znacząco obniżyć składkę na ubezpieczenie społeczne. Ustawodawca, przeciwdziałając temu zjawisku, zmodyfikował zasady zbiegu obu tytułów. W przypadku, gdy przychód ze zlecenia jest równy lub wyższy minimalnej podstawie wymiaru składki określonej dla osób prowadzących pozarolniczą działalność gospodarczą (zadeklarowana kwota nie jest niższa jednak niż $60 \%$ prognozowanego przeciętnego wynagrodzenia miesięcznego przyjętego do ustalenia kwoty ograniczenia rocznej podstawy wymiaru składek, ogłoszonego w trybie art. 19 ust. 10 SysUbSpołU na dany rok kalendarzowy), ustawodawca zezwala na wybór tytułu ubezpieczenia (por. wyrok SN z 2.08.2012 r., II UK 31/12, OSNAPiUS 2013, nr 17-18, poz. 212). Jeżeli podstawa wymiaru składki ze zlecenia jest niższa niż minimalna podstawa wymiaru składki dla osoby prowadzącej pozarolniczą działalność gospodarczą, ustawodawca wprowadza obowiązek ubezpieczenia z tytułu prowadzenia pozarolniczej działalności. W 2016 r., na mocy ustawy z 23.10.2014 r. o zmianie ustawy o systemie ubezpieczeń społecznych oraz niektórych innych ustaw (Dz.U. z 2014 r., poz. 1831 ze zm.), powyższe zasady rozciągnięto na pozostałe formy pozarolniczej działalności. W przypadku ubezpieczonych rozpoczynających prowadzenie pozarolniczej działalności i korzystających przez okres do 24 miesięcy z preferencyjnej składki określonej w art. 18 SysUbSpołU, ustawodawca wprowadził obowiązek ubezpieczeń emerytalnego i rentowych z obu tytułów.

Na gruncie powoływanej już nowelizacji z 2014 r. wprowadzono obowiązek kumulacji umowy zlecenia lub kilku zleceń oraz innych tytułów ubezpieczenia w sytuacji, gdy podstawa wymiaru składki ze zlecenia jest niższa niż wysokość minimalnego wynagrodzenia. Najczęściej spotykanym zastosowaniem tego przepisu jest kumulacja kilku umów zlecenia. Do 2016 r. obowiązkiem ubezpieczenia 
objęta była wyłącznie jedna z zawartych umów. Można więc było obniżyć należną składkę, zawierając kilka umów zlecenia i zgłaszając do ubezpieczenia tę, z której przychód był najniższy. Po zmianach, obowiązkiem ubezpieczenia objęte są wszystkie umowy zawarte przez ubezpieczonego, aż do osiągnięcia minimalnego wynagrodzenia. Przepis ten odpowiada analogicznemu rozwiązaniu zastosowanemu w przypadku stosunku pracy.

\section{SYTUACJA ZLECENIOBIORCY MAJĄCEGO USTALONE PRAWO DO EMERYTURY ALBO DO RENTY}

Liczne wątpliwości natury teoretycznej generowało objęcie ubezpieczeniem emerytalnym i rentowym zleceniobiorców mających ustalone prawo do emerytury albo do renty. Przyjęte rozwiązanie podyktowane było względami natury fiskalnej, w tym przede wszystkim potrzebą zwiększenia przychodów FUS. W piśmiennictwie obowiązek ubezpieczenia emerytów i rencistów oceniany jest krytycznie. Jak zauważyła I. Jędrasik-Jankowska, zajście ryzyka emerytalnego czyni zbędnym dalsze ubezpieczenie tego ryzyka. Zdaniem autorki, ubezpieczenie emerytalno-rentowe powinno obejmować wyłącznie zleceniobiorców mających ustalone prawo do renty (Jędrasik-Jankowska 2003, 110-111). Z takim twierdzeniem należy zgodzić się tylko częściowo. Przyjęta formuła emerytury umożliwia jej podwyższenie nie tylko poprzez opłacanie składek w okresie aktywności zarobkowej, ale także po jej zaprzestaniu. Znaczny odsetek ubezpieczonych, osiągając niskie świadczenie na starość, zmuszony będzie kontynuować aktywność zarobkową. Dotyczy to przede wszystkim osób osiągających niskie przychody, m.in. zleceniobiorców, których podstawa wymiaru składki jest z reguły niższa niż w przypadku pracowników. Zleceniobiorcy przez długi czas nie byli objęci minimalną stawką godzinową, co dodatkowo obniży ich świadczenia emerytalne i rentowe. Ponadto, po nabyciu prawa do emerytury, zlecenie stanowi formę zatrudnienia umożliwiającą elastyczne kształtowanie warunków umowy, charakteryzuje je brak uprawnień pracowniczych, co sprawia, że stanowi ono jedną z najczęściej wykorzystywanych w praktyce form zatrudnienia emerytów i rencistów. Możliwość przeliczenia świadczenia emerytalnego spełnia w takim przypadku dwie funkcje - po pierwsze umożliwia podwyższenie już nabytego świadczenia, a po drugie umożliwia nabycie prawa do emerytury minimalnej, o ile ubezpieczony nie spełnił przesłanki stażu w okresie aktywności zarobkowej.

W myśl ustawy zleceniobiorca mający ustalone prawo do emerytury albo do renty podlega obowiązkowo ubezpieczeniom emerytalnemu i rentowym w kilku przypadkach. Po pierwsze w sytuacji, gdy zlecenie stanowi jedyny tytuł ubezpieczenia. W takim przypadku będzie on podlegał ubezpieczeniu na zasadach analogicznych jak pozostali zleceniobiorcy. Nieco bardziej skomplikowane reguły obejmują sytuację zbiegu zlecenia z innym tytułem ubezpieczenia. W myśl 
art. 9 ust. 4a SysUbSpołU ustawodawca nakazuje objęcie obowiązkowym ubezpieczeniem zleceniobiorcy emeryta albo rencisty, o ile ten nie pozostaje jednocześnie w stosunku pracy. Jest to istotna różnica w stosunku do zbiegu zlecenia $\mathrm{z}$ innymi tytułami na zasadach ogólnych. Zgodnie z treścią art. 9 ust. 1 SysUbSpołU zleceniobiorca niebędący emerytem lub rencistą, a posiadający jednocześnie inny tytuł ubezpieczenia o bezwzględnym charakterze ${ }^{1}$, podlega z tytułu zlecenia dobrowolnemu ubezpieczeniu. Użycie w art. 9 ust. 4a SysUbSpołU pojęcia „,stosunek pracy" oznacza obowiązek ubezpieczenia emeryta lub rencisty w przypadku zbiegu z innymi niż stosunek pracy tytułami o bezwzględnym charakterze określonymi art. 9 ust. 1 SysUbSpołU. Rozszerzenie obowiązku ubezpieczenia poza stosunek pracy ma miejsce w przypadku, gdy umowa agencyjna, umowa zlecenia lub inna umowa o świadczenie usług, do której zgodnie z Kodeksem cywilnym stosuje się przepisy dotyczące zlecenia, albo umowa o dzieło, została zawarta $\mathrm{z}$ pracodawcą, z którym pozostają równocześnie w stosunku pracy, lub jeżeli w ramach takiej umowy wykonują pracę na rzecz pracodawcy, z którym pozostają w stosunku pracy. Przyjęte rozwiązanie stanowi powielenie obowiązku ubezpieczenia pracowników, wynikającego z art. 8 ust. 2a SysUbSpołU. W przypadku zleceniobiorcy emeryta albo rencisty, którego podstawa wymiaru składek na ubezpieczenia emerytalne $\mathrm{i}$ rentowe $\mathrm{w}$ danym miesiącu jest niższa od minimalnego wynagrodzenia, ustawodawca nakazuje objęcie ubezpieczeniem z innych tytułów, z których ubezpieczony podlega obowiązkowo ubezpieczeniom emerytalnemu i rentowym. Z uwagi na treść art. 9 ust. 5 SysUbSpołU, wprowadzającego dobrowolne ubezpieczenie emerytalne i rentowe w przypadku tytułów ubezpieczenia niewskazanych w art. 9 ust. 4-4c SysUbSpołU, przepis ten znajdzie zastosowanie przede wszystkim do kumulacji kilku umów zlecenia, tak aby łączna podstawa wymiaru składki na ubezpieczenie emerytalne i rentowe była równa lub wyższa kwocie minimalnego wynagrodzenia.

\section{SYTUACJA UCZNIÓW I STUDENTÓW WYKONUJĄCYCH UMOWĘ ZLECENIA}

Ustawa wprowadziła preferencje dla uczniów oraz studentów wykonujących pracę na podstawie umowy agencyjnej lub umowy zlecenia albo innej umowy o świadczenie usług, do której zgodnie z Kodeksem cywilnym stosuje się przepisy

${ }^{1}$ Zgodnie z art. 9 ust. 1 SysUbSpołU są to: stosunek pracy, umowa agencyjna, umowa zlecenia lub inna umowa o świadczenie usług, do której zgodnie z Kodeksem cywilnym stosuje się przepisy dotyczące zlecenia albo umowy o dzieło, jeżeli umowę taką zawarły z pracodawcą, z którym pozostają w stosunku pracy, lub jeżeli w ramach takiej umowy wykonują pracę na rzecz pracodawcy, z którym pozostają w stosunku pracy, członkostwo w spółdzielni, służba, pobieranie świadczenia szkoleniowego, świadczenia socjalnego, zasiłku socjalnego albo wynagrodzenia przysługującego w okresie korzystania ze świadczenia górniczego lub w okresie korzystania ze stypendium na przekwalifikowanie. 
dotyczące zlecenia. Na mocy art. 6 ust. 4 SysUbSpołU uczniowie szkół ponadpodstawowych lub studenci, do ukończenia 26 lat, nie podlegają ubezpieczeniom emerytalnemu i rentowym. Studenci oraz uczniowie świadczący pracę na innej podstawie niż zlecenie (np. umowa o pracę) podlegają ubezpieczeniu na ogólnych zasadach. Przyznana preferencja wynika z faktu, że osoby takie nie dysponują z reguły kwalifikacjami zawodowymi ani doświadczeniem zawodowym. W okresie studiów mogą więc nabyć niezbędne umiejętności, tak aby po ukończeniu edukacji posiadać kwalifikacje i doświadczenie niezbędne na rynku pracy. Ustawodawca poprzez niższe koszty zatrudnienia kompensuje tym samym brak doświadczenia zawodowego uczniów i studentów. Górna granica wieku wyłączająca preferencje uniemożliwia nadużywanie przyznanych uprawnień (np. podjęcie studiów zaocznych przez osobę dysponującą doświadczeniem zawodowym w celu zwolnienia ze składki na ubezpieczenie społeczne). W początkowym okresie po wejściu w życie ustawy (w latach 1999-2004), przy stosunkowo wysokiej stopie bezrobocia, zleceniodawcy zyskiwali - alternatywną w odniesieniu do stosunku pracy - formę zatrudnienia kierowaną do osób uczących się, która nie była obciążona ubezpieczeniem społecznym. Uczący się zleceniobiorcy zainteresowani ochroną ryzyka starości oraz inwalidztwa mogli w okresie studiów skorzystać $\mathrm{z}$ dobrowolnego ubezpieczenia emerytalnego i rentowego. Od 1999 roku prawo do dobrowolnego ubezpieczenia przysługiwało studentom oraz uczestnikom dziennych studiów doktoranckich. W roku 2003 preferencje rozciągnięto na wszystkich uczestników studiów doktoranckich, a w 2013 każda osoba nieubezpieczona (w tym także student i doktorant) zyskała prawo przystąpienia do dobrowolnego ubezpieczenia emerytalnego i rentowego. Od 2018 roku doktoranci otrzymujący stypendium podlegają obowiązkowemu ubezpieczeniu. Konstrukcja dobrowolnego ubezpieczenia emerytalnego i rentowych uregulowana w art. 7 SysUbSpołU sprawia, że osoby takie nie mogą jednak przystąpić do ubezpieczenia chorobowego, macierzyńskiego czy wypadowego (Krajewski 2014, 9 i n.). Ma to szczególne znaczenie w przypadku krótkoterminowej niezdolności do pracy lub ciąży osób uczących się oraz studentów, samodzielnie finansujących swoje utrzymanie. $Z$ uwagi na sposób zredagowania art. 6 ust. 4 SysUbSpołU (taksatywne wyliczenie szkół oraz uczelni), kolejne reformy systemu oświaty wymusiły modyfikację tego przepisu (przez wprowadzenie w 2001 roku gimnazjów, a następnie w 2017, wraz z powrotem do poprzedniego modelu systemu edukacji, przez wykreślenie gimnazjów ze szkół uprawniających do skorzystania z preferencji).

Od ogólnej zasady wyłączenia z ubezpieczenia osób uczących się a świadczących usługi przewidziano jeden wyjątek. Obejmuje on osoby świadczące pracę na podstawie umowy uaktywniającej. Odmienne uregulowanie, a więc objęcie ich obowiązkowym ubezpieczeniem, może wynikać z faktu, że składka na ubezpieczenie społeczne od podstawy stanowiącej kwotę nie wyższą niż 50\% wysokości minimalnego wynagrodzenia za pracę, ustalonego zgodnie z przepisami o minimalnym wynagrodzeniu za pracę, jest opłacana przez ZUS. Zgodnie z art. 50 
ust. 2 ustawy z 4.02.2011 r. o opiece nad dziećmi w wieku do lat 3 (Dz.U. z 2019 r., poz. 409 ze zm.) niania może sprawować opiekę nad dziećmi w wieku od ukończenia 20 tygodnia życia, zatem w przypadku zatrudnienia niani przed 20 tygodniem liczonym od dnia urodzenia dziecka podlega ona ubezpieczeniom na ogólnych zasadach (np. jako zleceniobiorca lub pracownik).

\section{MODEL OCHRONY ZLECENIOBIORCY. UWAGI DE LEGE FERENDA}

W ustawie o systemie ubezpieczeń społecznych ustawodawca wprowadził model autonomicznych obciążeń przypisanych do każdego tytułu ubezpieczenia. Model ten polega na zróżnicowaniu obciążeń określonych w oparciu o kryterium przynależności zawodowej. Ową autonomię najlepiej zobrazuje ukazanie różnych podstaw wymiaru składki dla trzech najczęściej występujących tytułów ubezpieczenia. W przypadku pracowników podstawę wymiaru składki stanowi skumulowany przychód ze wszystkich umów objętych tytułem ubezpieczenia pracowniczego (pełna kumulacja tytułów ubezpieczenia). Bez znaczenia jest to, czy umowy zostały zawarte $\mathrm{z}$ jednym czy z wieloma pracodawcami. W przypadku zleceniobiorców ustawodawca przewiduje obowiązek podlegania obowiązkowemu ubezpieczeniu emerytalnemu i rentowym z jednego tytułu (np. z jednej umowy zlecenia). Wyjątek od tej zasady stanowi sytuacja, gdy z umowy tej ubezpieczony nie osiąga minimalnego wynagrodzenia. W takim przypadku obowiązek ubezpieczenia rozszerzono na inne tytuły ubezpieczenia. Podstawę wymiaru składki stanowi co do zasady przychód, w wyjątkowych zaś sytuacjach - zadeklarowana kwota, nie niższa niż minimalne wynagrodzenie. W przypadku osób prowadzących działalność pozarolniczą obowiązkowym ubezpieczeniem obejmowany jest wyłącznie jeden tytuł ubezpieczenia. Ustawodawca wprowadził możliwość zadeklarowania podstawy wymiaru składki, a jednocześnie określił minimalną podstawę wymiaru składki, niezależną od osiąganego przychodu. W efekcie wysokość składki nie jest uzależniona od wyniku finansowego osiąganego przez przedsiębiorcę.

Zleceniobiorcy stanowią niejednorodną grupę ubezpieczonych, dlatego też trudno uchwalić przepisy uniwersalne, uwzględniające potrzeby każdej z wymienionych poniżej grup osób ubezpieczonych. Największą populację stanowią zleceniobiorcy, dla których zlecenie stanowi podstawowe źródło utrzymania. Wśród nich występują osoby posiadające niskie kwalifikacje i osiągające niskie dochody (zatrudnienie prekaryjne). $\mathrm{W}$ ich przypadku optymalny model ochrony powinien być zbliżony do ubezpieczenia pracowniczego. O ile w latach 90., przy wysokim bezrobociu i szarej strefie, stosunkowo trudno było ten cel osiągnąć, o tyle obecnie, przy niskiej stopie bezrobocia, skala zjawiska szarej strefy nie stanowi już tak istotnego zagrożenia dla wzmocnienia ochrony ubezpieczeniowej zleceniobiorców. Po drugie, coraz mniejszym zagrożeniem dla przychodów FUS jest 
nadużywanie umów o dzieło. Orzecznictwo sądowe ewoluuje bowiem w kierunku ograniczenia na gruncie ubezpieczeń społecznych swobody umów, uznawania kolejnych przejawów aktywności zarobkowej za świadczenie usług i obejmowania ich ochroną ubezpieczeniową.

Krytyce należy poddać także próg minimalnego wynagrodzenia, jako podstawy, do osiągnięcia której ustawodawca nakazuje kumulować tytuły ubezpieczenia. Przyjmując bowiem, że stopa zastąpienia dochodu z okresu aktywności zarobkowej (ewentualnie dochodu z końca aktywności zarobkowej) - świadczeniem emerytalnym i rentowym, wyniesie między $35 \%$ a $45 \%$, to wypłacane świadczenia oscylujące wokół emerytury minimalnej będą z pewnością niewystarczające, a dodatkowo wymagać będą uzupełnienia ze środków pochodzących z budżetu państwa. Wzmocnienie ochrony najniżej zarabiających zleceniobiorców jest moim zdaniem zasadne i konieczne.

Drugą grupę zleceniobiorców stanowią studenci. Wyłączenie ich z ubezpieczenia nie budzi większych kontrowersji, tym bardziej że mogą oni przystąpić do ubezpieczenia dobrowolnego. Wydaje się jednak, że ustawodawca powinien rozważyć możliwość objęcia uczniów i studentów ubezpieczeniem chorobowym i wypadkowym. Warto zauważyć, że zlecenie jest częstokroć jedynym źródłem utrzymania oraz podstawowym źródłem finansowania np. studiów. Wyłączenie studentów z ubezpieczenia chorobowego pozbawia takie osoby ochrony na wypadek ciąży, choroby, choroby zawodowej czy wypadku, jakich mogą doznać w trakcie wykonywania zlecenia.

Trzecią grupę stanowią osoby, dla których zlecenie stanowi źródło dodatkowego dochodu. Część z nich stanowią pracownicy, natomiast przeważają wysoko opłacani specjaliści świadczący usługi w ramach prowadzonej działalności pozarolniczej, która jest korzystniejsza niż zlecenie zarówno w aspekcie ubezpieczeń społecznych (możliwość zadeklarowania podstawy wymiaru składki czy zawieszenia prowadzonej działalności), jak i ze względów podatkowych (możliwość zaliczenia części wydatków w koszty uzyskania przychodu). W ich przypadku obecny model należy uznać za optymalny. Gwarantuje on możliwość doubezpieczenia z tytułu wykonywania umowy zlecenia czy też rezygnacji z ubezpieczenia i przeznaczenia zaoszczędzonych środków na inne cele, np. inwestycje, oszczędności czy bieżącą konsumpcję.

Konsekwencją wprowadzenia modelu autonomicznych obciążeń jest możliwość obniżenia należnej składki, poprzez m.in. zmianę tytułu ubezpieczenia (np. osoby zarobkujące w oparciu o umowy cywilnoprawne, przedsiębiorcy będący jednocześnie rolnikami) czy też zawarcie kilku umów w ramach jednego źródła dochodu (zleceniobiorcy). Jak łatwo zatem zauważyć, podstawową zaletą modelu autonomicznych obciążeń jest elastyczność systemu. Owa elastyczność nie obejmuje pracowników, co - jak wskazuje A. Reda-Ciszewska - uwidocznia dwie tendencje - ,zastępowanie umów o pracę umowami zlecenia, a następnie nadużywanie umów o dzieło" (Reda-Ciszewska 2015, 250). Istotne zróżnicowanie 
sytuacji pracowników i zleceniobiorców prowadzi do ucieczki od zatrudnienia pracowniczego na rzecz cywilnoprawnego. Odpowiadając na próby obniżania należnej składki, ustawodawca w drodze tzw. ustawodawstwa interwencyjnego wprowadza kolejne zmiany, które prowadzą do harmonizowania uprawnień obu grup zawodowych. Wprowadzane zmiany nie naruszają interesu pracowników (nie obniżają ich standardu ubezpieczenia), a rozszerzają z reguły obowiązek ubezpieczenia zleceniobiorców.

Model autonomicznych obciążeń poszczególnych tytułów ubezpieczenia posiada jednak niezwykle interesującą i wartą przemyślenia koncepcję alternatywną. Stanowi ją model jednolitego obciążenia tytułów ubezpieczenia. Jego istotą jest przyjęcie, że podstawę wymiaru składki stanowi skumulowana kwota przychodu osiągniętego przez ubezpieczonego ze wszystkich źródeł aktywności zarobkowej. Ustawodawca określa jedynie maksymalną w skali miesiąca lub roku podstawę wymiaru składki emerytalnej i rentowej (np. 24-krotność przeciętnego wynagrodzenia w roku kalendarzowym lub 2-krotność przeciętnego wynagrodzenia za każdy miesiąc podlegania ubezpieczeniom). Wprowadzenie ujednoliconych obciążeń ograniczyłoby potrzebę stosowania zbiegu tytułów w ubezpieczeniu emerytalnym i rentowym. System ten byłby sprawiedliwy, gdyż opierałby się na zasadzie solidarności społecznej. Największą z zalet postulowanego rozwiązania jest ograniczenie skutków multiplikacji tytułów. Skoro każdy płatnik, niezależnie od formy zatrudnienia, opłacałby składkę uzależnioną od osiągniętego wyniku finansowego, to system ubezpieczeń społecznych byłby neutralny w kwestii tzw. dumpingu socjalnego, czyli wypierania stosunku pracy przez umowy cywilnoprawne. Postulowane w doktrynie objęcie ubezpieczeniem także umów o dzieło zrównałoby status wszystkich pracobiorców (Kaczmarek 2010, 40 i n.).

Jak słusznie zauważyła M. Gersdorf, ,zrównanie ochrony w zakresie składki na ubezpieczenie jest krokiem w kierunku już postępującej ewolucji od prawa pracy na rzecz koncepcji prawa zatrudnienia" (Gersdorf 2018, 51 i n.). Ten naturalny kierunek zmian w prawie pracy powinien znaleźć swoje odzwierciedlenie także w prawie ubezpieczeń społecznych. Postulowane rozwiązanie ograniczyłoby konkurencję między umową o pracę a umową zlecenia, a tym samym wzmocniłoby swobodę zawieranych między stronami umów.

\section{ZAKOŃCZENIE}

Zleceniobiorcy stanowią jedną z najszybciej przyrastających grup ubezpieczonych. Popularyzacja tej formy zatrudnienia wynika przede wszystkim ze stosunkowo niskich obciążeń w ubezpieczeniach społecznych oraz braku uprawnień pracowniczych. Niski poziom obciążeń zleceniobiorcy wynika z celowego działania ustawodawcy, który usytuował umowę zlecenia na drugim poziomie, w hierarchii rządzącej zbiegami tytułów w ubezpieczeniach emerytalnym i rentowych 
(tytuły objęte zasadą pierwszeństwa w czasie). Przyjęta kompozycja umożliwia wyłączenie obowiązku ubezpieczenia zlecenia w zbiegu z pracą, a ponadto objęcie obowiązkiem ubezpieczenia w ograniczonym zakresie. Ograniczony poziom ochrony wywiera jednak negatywny wpływ tak na finanse publiczne, jak i przychody FUS.

Ubezpieczenie emerytalne i rentowe zleceniobiorców stanowi przedmiot licznych nowelizacji ustawy o systemie ubezpieczeń społecznych. Większość z nich dokonywana jest $\mathrm{w}$ ramach tzw. ustawodawstwa interwencyjnego, tzn. stanowi odpowiedź ustawodawcy bądź na wykorzystywanie zlecenia w celu obniżenia należnej składki, bądź też stanowi konsekwencję zmniejszających się przychodów FUS. Stąd też niezbędne jest wdrożenie nowego, uproszczonego modelu ubezpieczenia emerytalnego i rentowego, opartego na modelu jednolitego obciążenia źródeł dochodu. Umożliwi on odejście od tytułu ubezpieczenia jako kryterium wyznaczającego wysokość składki, a przejście do kryterium dochodu ustalanego niezależnie od źródła jego pochodzenia.

\section{BIBLIOGRAFIA}

Bińczycka-Majewska, Teresa. 2000. „Zbieg tytułów ubezpieczenia emerytalnego i rentowego w nowym systemie ubezpieczeń społecznych”. Praca i Zabezpieczenie Społeczne 12: 2-5.

Bińczycka-Majewska, Teresa. 2007. „Kumulacja i rozłączność tytułów ubezpieczenia społecznego". Praca i Zabezpieczenie Społeczne 1: 16-23.

Gersdorf, Małgorzata. 2018. „Jaka przyszłość: jeden kodeks zatrudnienia czy prawo zatrudnienia”. W Umowa o pracę a umowa o zatrudnienie. Red. G. Goździewicz. Warszawa: Lex a Wolters Kluwer business.

Jędrasik-Jankowska, Inetta. 1999. „Nowy system ubezpieczeń społecznych - wybrane problemy”. Praca i Zabezpieczenie Społeczne 3: 18-21.

Jędrasik-Jankowska, Inetta. 2003. Ubezpieczenie społeczne. Tom 1. Część ogólna. Warszawa: Wydawnictwo Prawnicze LexisNexis.

Jończyk, Jan. 2003. Prawo zabezpieczenia społecznego. Ubezpieczenia społeczne i zdrowotne: bezrobocie i pomoc społeczna. Kraków: Zakamycze.

Kaczmarek, Agnieszka. 2010. Zakres podmiotowy ubezpieczenia chorobowego. Iwonicz-Zdrój: Polskie Stowarzyszenie Ubezpieczenia Społecznego.

Krajewski, Marcin. 2014. „Dobrowolne ubezpieczenie emerytalne i rentowe na gruncie art. 7 i 10 ustawy o systemie ubezpieczeń społecznych”. Praca i Zabezpieczenie Społeczne 5: 9-15.

Krajewski, Marcin. 2018. „Obciążenia dochodów - w kierunku jednej daniny czy pozostawienia obecnego modelu obciążenia dochodów”. INFOS Biuro Analiz Sejmowych 7: 1-4.

Kurzych, Andrzej. 2015. „Multiplikacja podmiotów zatrudniających a stosunki ubezpieczenia społecznego". W Umowy cywilnoprawne w ubezpieczeniach społecznych. Red. Jacek Wantoch-Rekowski, Marzena Szabłowska-Juckiewicz, Monika Wałachowska. Warszawa: Wolters Kluwer Polska.

Reda-Ciszewska, Anna. 2015. „Cywilnoprawne umowy o zatrudnienie w prawie ubezpieczeń społecznych”. W Współczesne problemy prawa emerytalnego. Red. Teresa Bińczycka-Majewska, Mirosław Włodarczyk. Warszawa: Wolters Kluwer. 
Skoczyński, Jacek. 2000. „Zmiany regulacji obowiązku ubezpieczeń społecznych z tytułu świadczenia pracy na podstawie cywilnoprawnych umów o świadczenie usług”. Praca i Zabezpieczenie Spoteczne 2: 21-26.

\author{
Marcin Krajewski
}

\title{
THE CONCURRENCE OF PENSION AND DISABILITY INSURANCE OF THE CONTRACTOR SELECTED ISSUES
}

\begin{abstract}
The paper provides an analysis of advantages and disadvantages of being subject to social insurance by the contractors, under the Act on the social insurance system of 13 October 1998. The focus is placed on the principles of concurrence of titles in pension and disability insurance. The paper also provides an analysis of the current model of accumulation of titles in social insurance. In the last section of the paper the author presents the alternative model of consistently charging a premium on income of the insured.
\end{abstract}

Keywords: social insurance, pension insurance, contractor, contract of employment, civil-law contract. 